\title{
Effect of Yellowstripe scad (Selaroides leptolepis) protein hydrolysate in the reduction of oil uptake in deep-fried squid
}

\author{
${ }^{1,3}$ Hau, E.H., ${ }^{1}$ Amiza, M.A., ${ }^{1}$ Mohd Zin, Z., ${ }^{2}$ Shaharudin, N.A. and. ${ }^{1, *}$ Zainol, M.K. \\ ${ }^{1}$ Faculty of Fisheries and Food Science, Universiti Malaysia Terengganu, Mengabang Telipot, 21030 Kuala \\ Nerus, Terengganu, Malaysia \\ ${ }^{2}$ Department of Biochemistry, Faculty of Biotechnology and Biomolecule Sciences, Universiti Putra \\ Malaysia, 43400 UPM Serdang, Selangor, Malaysia \\ ${ }^{3}$ School of Biosciences, Taylor's University, 47500 Subang Jaya, Selangor, Malaysia
}

Article history:

Received: 30 April 2020

Received in revised form: 5

June 2020

Accepted: 8 June 2020

Available Online: 31 July

2020

Keywords:

Fish protein hydrolysate,

Reducing oil uptake,

Yellowstripe scad,

Deep-fried squid

DOI:

https://doi.org/10.26656/fr.2017.4(6).200

\begin{abstract}
Although the fried products are delicious with a tenderizing effect on the crust due to the presence of fat, over-consumption of fried products causes health problems, especially coronary diseases. The tendency of proteins in film formation and thermal gelation to reduce the absorption of oil in fried products is emphasized. The purpose of this study was to determine the reduction of oil in deep-fried squid by the incorporation of protein hydrolysate and to discuss its effect. Yellowstripe scad protein hydrolysate was produced using Alcalase ${ }^{\circledR}$ enzyme. Fat content was determined using the Soxhlet method, subsequently substituted into a formulation for oil uptake calculation. The viscosity of batter was determined using a rheometer. The viscosity of the batter and batter pick-up was found to be directly proportional, showing a significantly reduced pattern from 0 to $20 \%$. Incorporating $10 \%$ of fish protein hydrolysate successfully decreased oil absorption by $17.35 \pm 0.73 \%$ with a good water retention rate of $38.46 \%$. The addition of the Yellowstripe scad fish protein hydrolysate modified the size and shape of the pore. Sensory acceptance portrayed no significant difference among the three samples $(0 \%, 5 \%$ and $10 \%$ of incorporation), indicating that panellists were able to accept samples incorporated with fish protein hydrolysate. The findings of this study showed that Yellowstripe scad protein hydrolysate can minimize the uptake of oil in fried seafood products and thus could increase the economic value of the Yellowstripe scad fish.
\end{abstract}

\section{Introduction}

Yellowstripe scad belongs to a small group of pelagic fish known as low-value species and is one of South China Sea's plentiful marine sources (Bui and Toshiaki, 2014). Although supplies and outputs are relatively high, these fish are usually traded in fresh, frozen or dried snacks as well as in surimi for household consumption by fresh cooking or making fish cakes, generally in low-income families, while the low-quality Yellowstripe scad is used for aquaculture feed or livestock feed (Bui and Toshiaki, 2014). There is also a need to use these fish in a more advantageous way, as fish have a high amount of essential amino acids, namely methionine, lysine, tryptophan, cysteine and threonine, which play a vital role in the control of health and body nutrition (Dezhabadi et al., 2012).

Frying is one of the oldest cooking techniques, causing physical and chemical changes in food, but fried food is commonly associated with coronary heart disease because it contains high cholesterol, which can lead to obesity and many other health problems (Rimac-Brncic et al., 2004; Mirzaei et al., 2015). Therefore, fried food is also seen to be at the core of health issues (Falguera et al., 2011). There is also a need to reduce the amount of oil taken up by such goods, as oil has a major effect on wellbeing.

Batters are often used in frying to improve the quality of fried products by improving texture, flavour, weight and volume (Boskou et al., 2006). Apparently, the function of batter as the coating material is meant to reduce water loss during frying, subsequently reduce oil absorption. Besides, coating improves the structural integrity of the product, and retard gas transport so to prevent flavour diffusion to the oil (Kokoszka et al., 2010). Recently, the usage of protein as a coating 
material to reduce oil uptake in fried products has been focused due to its the ability in film-forming and thermal gelation properties in the batter (Brannan et al., 2014). This is because, protein can reduce pores on the batter, subsequently reduce oil uptake on fried products. Hence, many studies on protein to reduce oil uptake have been reported, for example, gelatine reduces oil uptake by $25 \%$ (Olson and Zoss, 1985), egg albumin reduces by 27\% (Myers and Brannan, 2012) and red snapper protein hydrolysate reduces oil uptake from $30 \%$ to $23 \%$ with $8 \%$ of incorporation (Chew et al., 2020). Fish protein hydrolysate has great potential to reduce oil uptake in fried products, however, the incorporation could be increased to determine the threshold of protein binding with other ingredients to form a good coating material. Thus, various potential protein hydrolysates need to be diversified as a natural oil reducer in fried seafood products. Therefore, this study aimed to determine the oil -uptake reduction by protein hydrolysate incorporated in batter in deep-fried squid.

\section{Materials and methods}

\subsection{Preparation of Yellowstripe scad fish protein} hydrolysate

About $50 \mathrm{~g}$ of fish meat was heated at $90^{\circ} \mathrm{C}$ for 10 mins and then mixed with $100 \mathrm{~mL}$ of sodium phosphate buffer at $\mathrm{pH}$ 8. The Alcalase ${ }^{\circledR}$ enzyme (Merck, USA) used were at a concentration of $2.0 \%$ and the hydrolysis was performed at $55^{\circ} \mathrm{C}$ for $2 \mathrm{hrs}$ at a constant $(220 \mathrm{rpm})$. The resulting fish protein hydrolysate was centrifuged at $10000 \mathrm{rpm}$ for $20 \mathrm{mins}$ and filtered using a cellulose filter (Whatman No.1, USA) (Hau, Amiza, Mohd Zin et al., 2018). The liquid hydrolysate was then freeze-dried (Labconco, USA) prior to incorporation in batter for further analysis (Hau, Mohd Zin, Zuraidah et al., 2018).

\subsection{Preparation of batter}

The quantities of dry ingredients used for the preparation of the batter are shown in Table 1. Water was added to the dry ingredients at a ratio of 1.5:1 (75 $\mathrm{mL}$ of water to $50 \mathrm{~g}$ of dry ingredients). The batter was then mixed well until a smooth mixture was obtained. Then, the batter was prepared with the incorporation of powdered protein hydrolysate instead of wheat flour. The white squid flesh used was cut to $3.5 \mathrm{~cm} \times 5.0 \mathrm{~cm}$ and dipped in the prepared batter ( 3 secs). The batter-coated squid was then deep-fried for approximately $1 \mathrm{~min}(160$ to $170^{\circ} \mathrm{C}$ ).

\subsection{Water binding capacity of batter}

A suspension of batter with the incorporation of protein hydrolysate was weighed and placed into a centrifuge tube. The mixture was let to agitate for $1 \mathrm{hr}$ at $25^{\circ} \mathrm{C}$ and centrifuged at $3000 \mathrm{rpm}$ for 10 mins. Free water was removed and drained for 10 mins. The weight of the pallet left in the centrifuge tube was recorded (Medcalf and Gilles 1965).

\subsection{Batter pick up}

The weight of the raw sample and the amount of coating picked up by the sample before frying were recorded (g) (Mukprasirt et al., 2000). The value was calculated based on Equation (1):

$$
\text { Percentage of batter pick up }(\%)=\frac{\text { Weight after coating }(g)}{\text { Weight before coating }(g)} \times 100
$$

\subsection{Flow behaviour}

The flow behaviour (viscosity) and time dependency were investigated using a $40 \mathrm{~mm}$ parallel plate rotational rheometer (DHR 2- TA Instrument) at $25 \pm 1^{\circ} \mathrm{C}$ (Dogan et al., 2005b). A drop of batter was placed in the flat plate and equilibrated for 2 mins and tested using $1 \mathrm{~mm}$ gap. A linear increasing rate from 0 to $200 \mathrm{~s}^{-1}$ in $300 \mathrm{~s}$ was set for sample shearing. The time dependency of batter was conducted by measuring the apparent viscosity under constant shear rate of $100 \mathrm{~s}^{-1}$ for $300 \mathrm{~s}$.

\subsection{Determination of fat content}

Approximately $1 \mathrm{~g}$ of crust was weighed and wrapped into a filter paper before placing it into a thimble. Extraction was conducted using petroleum ether. The system started with boiling, continued with rinsing, recovery and pre-drying steps. The extraction cup was removed and dried in the oven at $103^{\circ} \mathrm{C}$ for 2 hrs before weighing (AOAC, 2000). The percentage of fat was determined by Equation (2):

Percentage of fat content $(\%)=\frac{\text { Weight of } \mathrm{fat}(\mathrm{g})}{\text { Weight of smple }(g)} \times 100$

Table 1. Formulation of batter used for batter analysis and oil uptake determination

\begin{tabular}{cccccc}
\hline \multirow{2}{*}{ Sample } & \multicolumn{5}{c}{ Percentage for each ingredient (\%) } \\
\cline { 2 - 6 } & $\mathrm{A}$ & $\mathrm{B}$ & $\mathrm{C}$ & $\mathrm{D}$ & $\mathrm{E}$ \\
\hline Fish protein hydrolysate (FPH) (\%) & 0 & 5 & 10 & 15 & 20 \\
Wheat Flour (\%) & 30.2 & 25.2 & 20.2 & 15.2 & 10.2 \\
Rice flour (\%) & 65 & 65 & 65 & 65 & 65 \\
Sodium chloride (\%) & 3 & 3 & 3 & 3 & 3 \\
Sodium bicarbonate (\%) & 1 & 1 & 1 & 1 & 1 \\
Disodium pyrophosphate (\%) & 0.8 & 0.8 & 0.8 & 0.8 & 0.8 \\
\hline
\end{tabular}




\subsection{Oil uptake}

Oil uptake analysis is derived from fat content as described in 2.6, where oil uptake is the amount of fat content in sample against fat content of control sample ( $0 \%$ of incorporation), as shown in Equation (3) (Garmakhany et al., 2008):

Percentage of oil uptake $(\%)=\frac{F C(\text { incorporatedwith } F P H)-F C(\text { control) }}{F C(\text { control })} \times 100$

\subsection{Determination of moisture content}

The oven-drying method was used to determine the moisture content of samples. The samples were placed in the crucible and dried in an oven (Memmert, Germany) at $105^{\circ} \mathrm{C}$ until a constant weight was recorded (AOAC, 2000).

\subsection{Water retention}

The percentage of water retention was calculated using water content (WC) (as described in 2.8) of fried sample incorporated with fish protein hydrolysate (FPH) relative to the control (moisture content of fried sample with $0 \%$ incorporation), according to the formula shown in Equation (4) (Garmakhany et al., 2008).

$\%$ Water retention $=\frac{W C(\text { incorporated with FPH })-W C(\text { control })}{W C(\text { control })} \times 100$

\subsection{Microstructure of fried crust}

The samples were coated with $99 \%$ pure gold using JFC 1600 Auto fine coater, before being analysed using Scanning Electron Microscope (SEM) (Jeol-6360, USA). The specimen was viewed using 40X magnification (Hau, Mohd Zin, Zuraidah et al., 2018).

\subsection{Sensory acceptance}

Sensory analysis was conducted to identify the sensory acceptance of 40 untrained panellists using 7point Hedonic scale (7-like very much, 4-neither like nor dislike and 1-dislike very much) on attributes namely colour, smell, taste, texture, oiliness and overall acceptance (Zainol et al., 2020). The attributes were evaluated based on personal preference among the panellists on 3 samples presented to panellists, including 1 control $(0 \%$ incorporation $)$ were presented to panellists. The data were analysed using one-way ANOVA.

\subsection{Statistical analysis}

The statistical analysis for fried samples analysis was conducted by using SPSS software at the confidence level at $\alpha \leq 0.05$. The data obtained were analysed using one-way ANOVA to compare samples in different percentages of incorporation in the batter. Comparisons of means were carried out using Fisher's Least Significant Difference (LSD) test and the data were presented in the form of mean \pm standard deviation.

\section{Results and discussion}

\subsection{Water holding capacity}

There was no major difference in the water holding capacity of sample A (control - $0 \%$ incorporation) to $15 \%$ incorporation of fish protein hydrolysate. Batter with $20 \%$ incorporation, however, showed substantial difference $(\mathrm{p}<0.05)$ with to $0 \%$ incorporation, as shown in Table 2. High water binding ability of protein hydrolysate has been able to regulate the loss of moisture, reducing oil absorption during frying (Dogan et al., 2005b). Sample E exhibited the lowest value of all, possibly due to the inclusion of too much protein hydrolysate that reduced the efficiency of the batter ingredients (protein hydrolysate, flours, sodium chloride, sodium bicarbonate and disodium pyrophosphate) to bind together. Increasing the batter's water holding ability has shown to reduce oil absorption, as it prevents oil replacement of water. The finding was in line with the study by Holownia et al. (2000), who stated that the use of edible coating with high water holding ability could minimize fat absorption and increase the preservation of moisture. Batters with higher amounts of protein had a higher water holding capacity (Senthil et al., 2002). In addition to the surface properties, the water retained in batter plays a significant role in influencing texture and appearance (Chen et al., 2008).

\subsection{Viscosity}

Figure 1 indicates that increasing the amount of fish protein hydrolysate incorporation makes the batter

Table 2. Means of physicochemical analysis for different percentages of protein hydrolysate incorporation on batter, crust and flesh.

\begin{tabular}{ccccccc}
\hline Sample & Water holding capacity & Batter pick up & Fat content & Oil uptake & Moisture content Water retention \\
\hline A $(0 \%)$ & $66.14 \pm 2.66^{\mathrm{a}}$ & $50.41 \pm 2.95^{\mathrm{a}}$ & $60.40 \pm 2.21^{\mathrm{a}}$ & & $41.21 \pm 0.59^{\mathrm{b}}$ & \\
B $(5 \%)$ & $66.64 \pm 0.74^{\mathrm{a}}$ & $44.89 \pm 1.11^{\mathrm{ab}}$ & $55.50 \pm 2.33^{\mathrm{ab}}$ & $-9.87 \pm 3.32^{\mathrm{c}}$ & $52.85 \pm 5.53^{\mathrm{a}}$ & $29.67 \pm 3.59^{\mathrm{a}}$ \\
$\mathrm{C}(10 \%)$ & $66.56 \pm 2.15^{\mathrm{a}}$ & $34.29 \pm 1.81^{\mathrm{abc}}$ & $49.92 \pm 0.44^{\mathrm{bc}}$ & $-17.35 \pm 0.73^{\mathrm{b}}$ & $53.21 \pm 1.53^{\mathrm{a}}$ & $38.46 \pm 6.08^{\mathrm{a}}$ \\
D (15\%) & $65.13 \pm 1.81^{\mathrm{a}}$ & $30.68 \pm 0.13^{\mathrm{bc}}$ & $46.11 \pm 2.60^{\mathrm{cd}}$ & $-23.66 \pm 4.31^{\mathrm{ab}}$ & $43.21 \pm 1.35^{\mathrm{b}}$ & $16.42 \pm 3.11^{\mathrm{b}}$ \\
E (20\%) & $59.43 \pm 1.74^{\mathrm{b}}$ & $23.66 \pm 0.27^{\mathrm{c}}$ & $41.03 \pm 2.11^{\mathrm{d}}$ & $-32.07 \pm 3.50^{\mathrm{a}}$ & $41.47 \pm 2.60^{\mathrm{b}}$ & $-5.15 \pm 1.11^{\mathrm{c}}$ \\
\hline
\end{tabular}

Values are expressed as mean \pm SD. Means with same letter superscript are insignificantly different ( $p>0.05)$ in each column. 
thinner. Sample A (control - 0\% incorporation of FPH) showed the batter was most viscous followed by $5 \%$, $10 \%, 15 \%$, and $20 \%$, respectively. The viscosity of batter was directly related to the water binding capacity of dry ingredients (Dogan et al., 2005b). Batter with $0 \%$ of protein hydrolysate incorporation had the highest viscosity, probably due to the strongest binding strength among the batter ingredients. Substituting flour with fish protein hydrolysate causes the viscosity of batter to reduce as the binding strength of other batter ingredients, especially flour as the thickening agent, could be reduced. This is in agreement with the previous study which reported that developing viscosity in batter depends on structural association, the solubility of other ingredients and molecular weight of components (Seyhan et al., 2005; Meyer, 1989). Altunakar et al. (2006) deduced that viscosity of batter developed was dependent on water binding capacity of the ingredients. Ingredients that bind higher quantities of water will form a higher consistency batter, but the most appropriate batter should be in moderate consistency because the viscous batter may result in excessive oil absorption while the too diluted batter produces unsatisfactory coating.

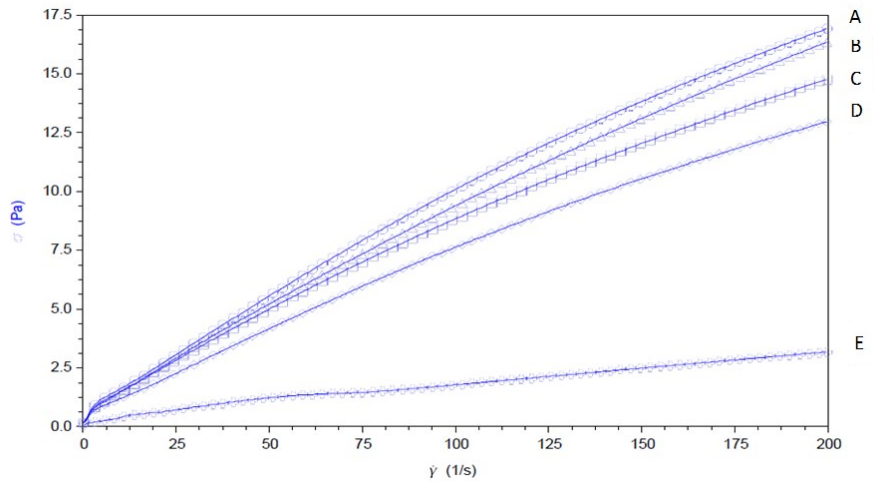

Figure 1. Flow behaviour of batter incorporated with different percentage of protein hydrolysate. A- $0 \%, \mathrm{~B}-5 \%$, C- $10 \%$, D$15 \%$ and $\mathrm{E}-20 \%$ incorporation of $\mathrm{FPH}$

\subsection{Batter pick up}

Table 2 portrays the highest batter pick-up was $0 \%$ of protein hydrolysate incorporation. The result showed a reducing trend starting with $50.4 \%$ (A), $44.9 \%$ (B), $34.3 \%$ (C), 30.7\% (D) and $23.7 \%$ (E), significantly different $(p<0.05)$ from each other, as the incorporation of fish protein hydrolysate varied from $0 \%$ to $20 \%$. This could be due to reducing the viscosity of the batter as the incorporation of fish protein hydrolysate increased. Batter pick-up was found to be directly proportional to batter viscosity, which was in accordance with the study by Dogan et al. (2005b). Altunakar et al. (2004) and Dogan et al. (2005a) reported that correlation between batter viscosity and batter pick up, at which increasing batter pick up is due to increased viscosity of batter. The higher consistency batters give higher batter pick up, with the correlation up to $r=0.98$, whereas the consistency of the batter is largely dependent on the ingredients and other parameters (Gamonpilas et al., 2013). A good film-forming and thermal gelling ability is a crucial property in the batter to reduce oil uptake because uniform coating formation and stronger coating with smaller pore size are essential to minimise mass transfer during frying (Balasubramaniam et al., 1997; Huse et al., 1998; García et al., 2002; Garmakhany et al., 2008).

\subsection{Fat determination (oil uptake) on fried crust}

Table 2 also shows that as the incorporation of protein hydrolysate increased from $0 \%$ to $20 \%$, fat content reduced from $60 \%$ to $55 \%, 50 \%, 46 \%$ and $41 \%$. A significant difference $(p<0.05)$ was observed between protein hydrolysate incorporation and fat content on fried crust. Oil uptake showed a reducing trend as the percentage of incorporation increased, where the samples had significant interaction $(p<0.05)$ among the percentage of incorporation. As the incorporation increased from $5 \%$ to $20 \%$, the oil reduction increased from $10 \%$ to $32 \%$, suggesting that the addition of protein hydrolysate could reduce oil uptake. The result was in agreement with Zainol et al. (2020) who reported that Toothpony fish protein hydrolysate reduced fat content in fried seafood products. Proteins were being emphasized in several previous studies to reduce oil uptake due to the ability in film-forming and thermal gelation properties (Brennan et al., 2014). Cross-linking of protein could also reduce the porosity in the sample, which will reduce oil absorption (up to 30\%). Mohamed et al. (1998) reported that batter coating reduces moisture loss during frying, subsequently reducing oil absorption. Oil uptake showed a reducing trend as the amount of protein hydrolysate increased because of the functional properties of protein to reduce moisture loss during frying. Even though the oil-uptake reduction in samples C and D was higher than the other samples, it is not preferable, as the reduction could be attributable to the lower crust formed during frying, so that less oil is contained in the crust. Angor (2016) and Dogan et al. (2005b) reported that different amounts of hydrocolloid, especially protein hydrolysate, may reduce the oil uptake of fried products to varying degrees.

\subsection{Moisture content (water retention) on flesh of squid}

Table 2 shows that sample C (10\% incorporation) was significantly higher than sample $\mathrm{A}, \mathrm{D}$ and $\mathrm{E}$ in moisture content and water retention. This data strongly suggests that $10 \%$ incorporation of fish protein hydrolysate was the best formula to retain moisture in fried products, subsequently reducing oil uptake. Table 2 also shows the percentage of water retained in the fried 
sample as the incorporation of protein hydrolysate increased. As the percentage of incorporation increased to $10 \%$, water retention increased to $38 \%$ but dropped to $16 \%$ then to $-5 \%$. This showed that crusts with 0 to $10 \%$ of incorporation retained water positively and successfully reduced oil uptake. This is because water retained is inversely proportional to oil absorption (Mellema, 2003).

The increase in water retention and reduction in oil absorption could be due to incorporation of ingredients as coating film was also agreed by Freitas et al. (2009). Protein can control moisture loss, subsequently oil uptake due to its high water binding capacity (Dogan et al., 2005b). Sakhale and Pahade (2012) reported that oil absorption could be prevented by the hydrocolloids through the ability of film-forming, hence increasing moisture retention in the product. Thus, incorporation of protein hydrolysate to $10 \%$ showed somewhat a positive effect in reducing oil uptake but $15 \%$ and $20 \%$ gave a somewhat negative effect. Lower water retention could be caused by lesser crust formed. Water in the sample could not be retained by the thin crust which acts as a barrier that prevents moisture loss. This probably due to the properties of protein hydrolysate as the batter formed was less viscous as the percentage of incorporation increases. Crust formation is required to limit mass transfer during frying. Thus, lesser crust formation could not absorb oil and retain water in the sample, causing a negative result in water retention as shown in Table 2.

\subsection{Microstructure of fried crust}

Figure 2 illustrates the influence of different percentages of protein incorporation on the crust of battered squid after deep frying. Sample A with $0 \%$ incorporation illustrated that the crust had many large and deep pores on the crust, while sample B had large and many small pores. Sample C with $10 \%$ incorporation had many pores but the pores were shallow with layering at the bottom, whereas sample D had many large pores. Sample E had no notable pores, probably because a layer of skin from the sample was stuck to the crust since a very thin layer of batter-coated on the sample. Porosity on fried crust showed consensus with oil uptake analysis, showing that lesser oil absorbed as fish protein hydrolysate incorporation elevated. Smaller pores seen as the percentage of incorporation increased because of thermal gelation and film-forming properties shown by fish protein hydrolysate (Angor, 2014). Dragich and Krochta (2010) suggested that protein altered the surface structure of fried samples by filling the pores, in order to reduce empty space for oil absorption.

Protein hydrolysate in batter altered the size and shape of the pores supported the oil uptake analysis, at

which smaller and shallower pores absorbed lesser oil. There was consensus with the previous study where larger pores on crust drawn more oil adhere to the surface of the crust when a sudden drop in internal pressure due to water vapour condensation creates a vacuum-effect (Ufheil and Escher, 1996; Brennan et al., 2014). The oil absorbed in this study relied largely on the microstructure of the crust, suggesting that fried crust plays a vital role in oil absorption.

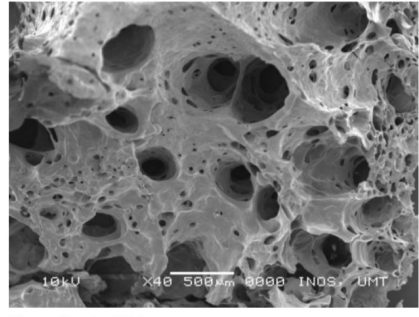

Sample $\mathrm{A}=0 \%$

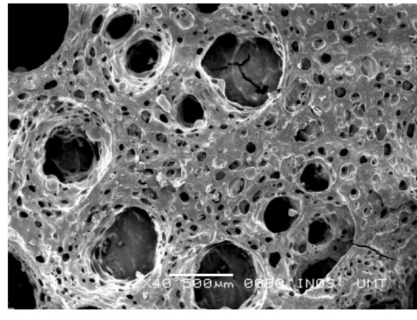

Sample $\mathrm{C}=10 \%$

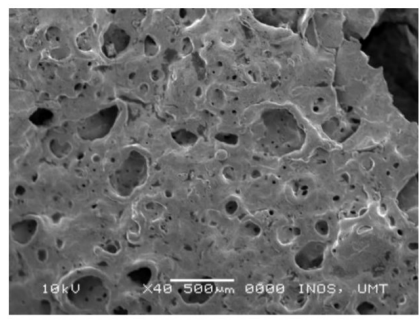

Sample E=20\%

Figure 2. The effect of protein hydrolysate incorporation on the microstructure of crust

\subsection{Sensory acceptance on fried products}

Table 3 shows that there was no significant difference $(p>0.05)$ between samples incorporated with different percentages of fish protein hydrolysate in each attribute. This showed that the panellists were able to accept samples incorporated with protein hydrolysate. The previous study reported that consumers prefer fried food despite health diseases due to better taste (Garmakhany et al., 2008). Thus, this study proved that incorporating protein hydrolysate in batter could be accepted (taste, appearance and texture) with lower oil absorbed in fried samples, based on the personal preferences of panellists. Kilincceker et al. (2009) suggested that the smell, taste and flavour of fried products were improved using coating material. Chew et al. (2020) reported that incorporation of Brownstripe red snapper (Lutjanus vitta) protein hydrolysate increases the overall acceptability of fried squid. Generally, panellists were able to identify samples with lower oiliness and 
Table 3. Sensory acceptance scores for different percentage of incorporation in batter

\begin{tabular}{ccccccc}
\hline & Appearance & Smell & Taste & Oiliness & Texture & Overall preference \\
\hline A (0\%) & $5.55 \pm 1.26^{\mathrm{a}}$ & $5.30 \pm 1.51^{\mathrm{a}}$ & $5.38 \pm 1.25^{\mathrm{a}}$ & $4.93 \pm 1.40^{\mathrm{a}}$ & $5.40 \pm 1.61^{\mathrm{a}}$ & $5.40 \pm 1.36^{\mathrm{a}}$ \\
B (5\%) & $5.07 \pm 1.54^{\mathrm{a}}$ & $5.50 \pm 1.41^{\mathrm{a}}$ & $5.65 \pm 1.29^{\mathrm{a}}$ & $4.53 \pm 1.84^{\mathrm{a}}$ & $5.48 \pm 1.38^{\mathrm{a}}$ & $5.58 \pm 1.22^{\mathrm{a}}$ \\
$\mathrm{C}(10 \%)$ & $5.33 \pm 1.27^{\mathrm{a}}$ & $5.28 \pm 1.20^{\mathrm{a}}$ & $4.93 \pm 1.49^{\mathrm{a}}$ & $5.05 \pm 1.60^{\mathrm{a}}$ & $5.35 \pm 1.46^{\mathrm{a}}$ & $5.05 \pm 1.52^{\mathrm{a}}$ \\
\hline
\end{tabular}

Values are expressed as mean \pm SD. Means with same letter superscript are insignificantly different $(\mathrm{p}>0.05)$ in each column.

these panellists were able to accept the taste and smell of the fried sample incorporated with protein hydrolysate.

\section{Conclusion}

The incorporation of Yellowstripe scad fish's protein hydrolysate in batter clearly expressed its ability in reducing oil uptake. The most optimum percentage of incorporation was shown to be at $10 \%$ of incorporation, at which the moisture retention was the highest with optimum oil reduction. Besides, a clear SEM image indicating protein hydrolysate was able to form film that reduces pore size which accommodates oil compounds. Hence, incorporating $10 \%$ of protein hydrolysate has successfully reduced oil uptake, with high potential to be applied to the food industry. The outcomes of this study are beneficial in further exploring the usage of these functional proteins, increasing the value of Yellowstripe scad fish by utilizing them as value-added components in food. The world, where a healthy driven society focused on natural products to boost better living, exploring the amino acid compositions, sequencing and other bioactivities in the future study can widen the application in nutraceutical and food sciences.

\section{Conflict of interest}

The authors declare that there is no conflict of interest.

\section{Acknowledgement}

Deepest appreciation to the Ministry of Higher Education (FRGS grant - Vot 59372) for financial support and UMT for lab facilities.

\section{References}

Altunakar, B., Sahin, S. and Sumnu, G. (2004). Functionality of batters containing different starch types for deep-fat frying of chicken nuggets. European Food Research and Technology, 218, 318 -322. https://doi.org/10.1007/s00217-003-0854-5.

Altunakar, B., Sahin, S. and Sumnu, G. (2006). Effects of hydrocolloids on apparent viscosity of batters and quality of chicken nuggets. Chemical Engineering Communications, 193(6), 675-682. https:// doi.org/10.1080/00986440500194069.

Angor, M.M (2014). Application of whey protein and whey protein isolate as edible coating films on potato pellets chips to reduce oil uptake during deep frying. Contemporary Engineering Sciences, 7(34), 1839-1851.

https://doi.org/10.12988/ ces. 2014.410194

Angor, M.M. (2016). Reducing fat content of fried potato pellet chips using carboxymethyl cellulose and soy protein isolate solutions as coating films. Journal of Agricultural Science, 8(3), 162-168. https://doi.org/10.5539/jas.v8n3p162.

AOAC. (2000). Official methods of analysis. 17th ed. Washington DC, USA: Association of Official Analytical Chemists.

Balasubramaniam, V.M., Chinnan, M.S., Mallikarjunan, P. and Phillips, R.D. (1997). The effect of edible film on oil uptake and moisture retention of a deepfat fried poultry product. Journal of Food Process Engineering, 20(1), 17-29. https://doi.org/10.1111/ j.1745-4530.1997.tb00408.x.

Brannan, R.G., Mah, E., Schott, M., Yuan, S., Casher, K.L., Myers, A. and Herrick, C. (2014). Influence of ingredients that reduce oil absorption during immersion frying of battered and breaded foods. European Journal Lipid Science Technology, 116(3), 240-254. https://doi.org/10.1002/ejlt.201200308.

Boskou, G., Salta, F.N., Chiou, A., Troullidou, E. and Andrikopoulos, N.K. (2006). Content of trans, trans2,4-decadienal in deep-fried and pan-fried potatoes. European Journal Lipid Science Technology, 108(2), 109-115. https://doi.org/10.1002/ejlt.200500236.

Bui, T.N.T.V. and Toshiaki, O. (2014). The stability of bioactive compounds in Yellowstripe Scad (Selaroides leptolepis) under subatmospheric pressure storage. International Journal of Research in Agriculture and Food Science, 2(2), 23-28.

Chen, H.H., Kang, H.Y. and Chen, S.D. (2008). The effects of ingredients and water content on the rheological properties of batters and physical properties of crusts in fried foods. Journal of Food Engineering, 88(1), 45-54. https://doi.org/10.1016/ j.jfoodeng.2008.01.017.

Chew, R.M., Mohd Zin, Z., Ahmad, A., Mohtar, N.F., Rusli, N.D. and Zainol, M.K. (2020). Physicochemical and sensory properties of deepfried battered squid containing Brownstripe red snapper (Lutjanus vitta) protein hydrolysate. Food 
Research, 4(4), 1245-1253. https://doi.org/10.26656/ fr.2017.4(4).083.

Dezhabadi, A., Dalirie, M.S. and Toudar, S. (2012). Amino acid profile of kutum (Rutilus frisii), silver carp (Hypophthalmicthys molitrix) and rainbow trout (Onchorhynchus mykiss). African Journal of Agricultural Research, 7(34), 4845-4849. https:// doi.org/10.5897/AJAR11.2067.

Dogan, F.S., Sahin, S. and Sumnu, G. (2005a). Effects of batters containing different protein types on the quality of deep-fat-fried chicken nuggets. European Food Research Technology, 220, 502-508. https:// doi.org/10.1007/s00217-004-1099-7.

Dogan, F.S., Sahin, S. and Sumnu, G. (2005b). Effects of soy and rice flour addition on batter rheology and quality of deep-fat fried chicken nuggets. Journal of Food Engineering, 71(1), 127-132. https:// doi.org/10.1016/j.jfoodeng.2004.10.028.

Dragich, A. and Krochta, J. (2010). Whey protein solution coating for fat-uptake reduction in deepfried chicken breast strips. Journal of Food Science, 75(1), S43-S47. https://doi.org/10.1111/j.17503841.2009.01408.x.

Falguera, V., Quintero, J., Jiménez, A., Muñoz, J. and Ibarz, A. (2011). Edible films and coatings: Structures, active functions and trends in their use. Trends Food Science and Technology, 22(6), 292303. https://doi.org/10.1016/j.tifs.2011.02.004.

Freitas, D.D.G.C., Berbari, S., Prati, P., Fakhouri, F., Queiroz, F. and Vicente, E. (2009). Reducing of fat uptake in cassava product during deep-fat frying. Journal of Food Engineering, 94(3-4), 390-394. https://doi.org/10.1016/j.jfoodeng.2009.04.005.

Gamonpilas, C., Pongjaruvat, W., Methacanon, P., Seetapan, N., Fuongfuchat, A. and Klaikherd, A. (2013). Effects of cross-linked tapioca starches on batter viscosity and oil absorption in deep-fried breaded chicken strips. Journal of Food Engineering, 114(2), 262-268. https:// doi.org/10.1016/j.jfoodeng.2012.08.008.

García, M.A., Ferrero, C., Campana, A., Bértola, N., Martino, M. and Zaritzky, N. (2002). Edible coatings from cellulose derivatives to reduce oil uptake in fried products. Innovative Food Science and Emerging Technologies, 3(4), 391-397.

Garmakhany, A.D., Mirzaei, O.H., Nejad, M.K. and Maghsudlo, Y. (2008). Study of oil uptake and some quality attributes of potato chips affected by hydrocolloids. European Journal Lipid Science and Technology, 110(11), 1045-1049. https:// doi.org/10.1002/ejlt.200700255.

Mirzaei, O.H., Salehi, F., Garoumi, H. and Ferhadpour,
F. (2015). Roles of MC compounds at less of oil absorption of French fries potato. Journal of Nutritional Health and Food Engineering, 2(5), 1-3. https://doi.org/10.15406/jnhfe.2015.02.00075.

Hau, E.H., Amiza, M.A., Mohd Zin, Z. and Zainol, M.K. (2018). The properties, compositions and qualities of Yellowstripe scad (Selaroides leptolepis) and its liquid protein hydrolysate based on different enzyme concentrations, hydrolysis time and choice of buffer. International Food Research Journal, 25(3), 11741180.

Hau, E.H., Mohd Zin, Z., Zuraidah, N., Shaharudin, N.A. and Zainol, M.K. (2018). Physicochemical properties of powdered protein hydrolysate from Yellowstripe scad (Selaroides leptolepis) fish. International Food Research Journal, 25(6), 2553-2559.

Holownia, K., Chinnan, M., Erickson, M. and Mallikarjunan, P. (2000). Quality evaluation of edible film-coated chicken strips and frying oils. Journal of Food Science, 65(6), 1087-1090. https:// doi.org/10.1111/j.1365-2621.2000.tb09423.x.

Huse, H.L., Mallikarjunan, P., Chinnan, M.S., Hung, Y.C. and Phillips, R.D. (1998). Edible coatings for reducing oil uptake in production of Akara (deep-fat frying of cowpea paste). Journal of Food Processing and Preservation, 22(2), 155-165. https:// doi.org/10.1111/j.1745-4549.1998.tb00811.x

Kilincceker, O., Dogan, I. and Kucukoner, E. (2009). Effect of edible coatings on the quality of frozen fish fillets. LWT-Food Science and Technology, 42(4), 868-873. https://doi.org/10.1016/j.lwt.2008.11.003

Kokoszka, S., Debeaufort, F., Hambleton, A. and Voilley, A. (2010). Protein and glycerol contents affect physico-chemical properties of soy protein isolate-based edible films. Innovative Food Science and Emerging Technologies, 11(3), 503-510. https:// doi.org/10.1016/j.ifset.2010.01.006.

Medcalf, D.G. and Gilles, K.A. (1965). Wheat starches: I. Comparison of physicochemical properties. Cereal Chemistry, 42, 558-567.

Mellema, M. (2003). Mechanism and reduction of fat uptake in deep fat fried foods. Trends Food Science Technology, 14(9), 364-373. https://doi.org/10.1016/ S0924-2244(03)00050-5.

Mohamed, S., Hamid, N.A. and Hamid, M.A. (1998). Food components affecting the oil absorption and crispiness of fried batter. Journal of the Science of Food and Agriculture, 78(1), 39-45. https:// doi.org/10.1002/(sici)1097-0010(199809)

78:1<39::aid-jsfa82>3.0.co;2-g.

Mukprasirt, A., Herald, T.J. and Flores, R.A. (2000). Rheological characterization of rice flour-based 
batters. Journal of Food Science, 65(7), 1194-1199. https://doi.org/10.1111/j.1365-2621.2000.tb10264.x.

Myers, A.S. and Brannan, R.G. (2012). Efficacy of fresh and dried egg white on inhibition of oil absorption during deep fat frying. Journal of Food Quality, 35 (4), 239-246. https://doi.org/10.1111/j.17454557.2012.00454.x.

Olson, S. and Zoss, R. (1985). Fried foods of reduced oil absorption and methods of preparation employing spray of film forming agent. United States Patent 4511583. Washington, DC, USA: U.S. Patent and Trademark Office

Rimac-Brncic, S., Lelas, V., Rade, D. and Simundic, B. (2004). Decreasing of oil absorption in potato strips during deep fat frying. Journal of Food Engineering, 64(2), 237-241. https://doi.org/10.1016/ j.jfoodeng.2003.10.006.

Sakhale, B.K. and Pahade, P.K. (2012). Effect of blanching and coating with hydrocolloids on reduction of oil uptake in French fries. International Food Research Journal, 19(2), 697-699.

Senthil, A., Ravi, R., Bhat, K.K. and Seethalakshmi, M.K. (2002). Studies on the quality of fried snacks based on blends of wheat flour and soya flour. Food Quality and Preference, 13(5), 267-273. https:// doi.org/10.1016/S0950-3293(02)00023-X.

Ufheil, G. and Escher, F. (1996). Dynamics of oil uptake during deep fat frying of potato slices. LWT-Food Science and Technology, 29(7), 640-644. https:// doi.org/10.1006/fstl.1996.0097.

Zainol, M.K., Tan, R.C., Mohd Zin, Z., Ahmad, A. and Danish-Daniel, M. (2020). Effectiveness of Toothpony (Gazza minuta) protein hydrolysate on reducing oil uptake upon deep-frying. Food Research, 4(3), 805 - 813. https://doi.org/10.26656/ fr.2017.4(3).392. 